Article

\title{
Novel Dual Walling Cob Building: Dynamic Thermal Performance
}

\author{
Kaoutar Zeghari ${ }^{1}$, Ayoub Gounni ${ }^{1}$, Hasna Louahlia 1,*(D), Michael Marion ${ }^{1}$, Mohamed Boutouil ${ }^{2}$, \\ Steve Goodhew ${ }^{3}$ (D) and François Streif ${ }^{4}$
}

1 LUSAC Laboratory, University of Caen Normandie, Site Universitaire Bellevue, 50000 Saint Lô, France; Kaoutar.zeghari@unicaen.fr (K.Z.); Ayoub.gounni@unicaen.fr (A.G.); michael.marion@unicaen.fr (M.M.)

2 ESITC Caen, Campus 2, 14610 Epron, France; mohamed.boutouil@esitc-caen.fr

3 School of Art, Design and Architecture, University of Plymouth, Drake Circus, Plymouth PL4 8AA, UK; S.Goodhew@plymouth.ac.uk

4 PNRMCB, St-Côme-du Mont, 50500 Carentan Les Marais, France; fstreiff@parc-cotentin-bessin.fr

* Correspondence: hasna.louahlia@unicaen.fr; Tel.: +33-233-775-518

Citation: Zeghari, K.; Gounni, A.; Louahlia, H.; Marion, M.; Boutouil, M.; Goodhew, S.; Streif, F. Novel Dual Walling Cob Building: Dynamic Thermal Performance. Energies 2021, 14, 7663. https://doi.org/10.3390/ en14227663

Academic Editor: Alfredo Guardo Zabaleta

Received: 30 August 2021

Accepted: 5 November 2021

Published: 16 November 2021

Publisher's Note: MDPI stays neutral with regard to jurisdictional claims in published maps and institutional affiliations.

Copyright: (c) 2021 by the authors. Licensee MDPI, Basel, Switzerland. This article is an open access article distributed under the terms and conditions of the Creative Commons Attribution (CC BY) license (https:/ / creativecommons.org/licenses/by/ $4.0 /)$.

\begin{abstract}
This paper emphasizes the experimental and numerical study of new cob mixes used for insulation and load bearing wall elements. The experimental study provides complete datasets of thermal properties of the new walling materials, using cob with density ranging from $1107 \mathrm{~kg} / \mathrm{m}^{3}$ to $1583 \mathrm{~kg} / \mathrm{m}^{3}$ for structural walls and less than $700 \mathrm{~kg} \mathrm{~m}^{-3}$ for insulation walls. Various mixes of French soils and fibres (reed, wheat straw, hemp shiv, hemp straw, and flax straw) with different water contents are studied. The lowest average thermal conductivity is obtained for the structural cob mix prepared of $5 \%$ wheat straw and $31 \%$ of water content. The insulation mix, prepared with $25 \%$ reed and $31 \%$ water content, has the lowest thermal conductivity. Investigation of diffusivity, density, and heat capacity shows that, when thermal conductivity is lower than $0.4 \mathrm{~W} \mathrm{~m}^{-1} \mathrm{~K}^{-1}$, the decrease in cob density leads to better insulation values and higher heat capacity. Little variation is noticed regarding the density and heat capacity for cob mixes with thermal conductivity higher than $0.4 \mathrm{~W} \mathrm{~m}^{-1} \mathrm{~K}^{-1}$. Furthermore, the non-uniformity of local thermal conductivity and heat losses through the samples is due mainly to the non-uniform distribution of fibres inside the mixes inducing an increase in heat loss up to $50 \%$ for structural walls and $25 \%$ for insulation walls. Cob thermal properties are used in a comparative simulation case study of a typical house under French and UK climatic conditions. The energy performance of the conventional building is compared to a dual walled cob building, showing remarkable reduction in energy consumption as the cob walls, whilst maintaining comfortable indoor conditions without additional heating.
\end{abstract}

Keywords: earth construction; cob-building; building performance; dynamic simulation; heating energy; sustainable thermal comfort

\section{Introduction}

Recently, the emerging interest in earthen vernacular building materials is increasing both for historical earth buildings renovation and maintenance, as well as investing in new earth construction techniques in order to meet the actual thermal regulations [1]. The International Energy Agency (IEA) stated, in its last report of June 2020, that building energy use grew 7.81\% from 2010 to 2019 [2]. This remains intense as the offset service demand keeps growing, which requires more investment in sustainable development programs at the building sector. Indeed, different policies have been adopted to promote energy efficiency and sustainable building practices [3], while other improvement scenarios are expected to be accomplished by 2030, such as: deep energy renovations, a tripling of heat pumping technology, 50\% of air conditioning. Indeed, earth building reduces the building energy need, offers low greenhouse gas emissions, and lowers the energy needed for recycling [4]. Earthen architecture incorporates various building techniques 
such as rammed earth, cob, 'wattle and daub', and poured earth. For instance, cob material comprises a mix of clay-based sub-soil and fibres (often straw) used to build a monolithic wall through superposition of a series of lifts beaten with a wood element.

Several studies have been conducted to characterize thermal properties of earth materials including Cob through laboratory scale measurements or in-situ heat flux assessment case studies since building thermal performance has a major impact on building energy consumption. Goodhew and Griffiths [5] measured the thermal conductivity and diffusivity of un-fired clay bricks, straw clay mixture, and straw bales by means of a thermal probe technique using iterative method for data analysis. They also presented time-dependent thermal properties of earth walls and the steady-state air-to-air thermal transmittance. Mansour et al. [6] found that the use of optimal bulk density of $1750 \mathrm{~kg} / \mathrm{m}^{3}$ reduces thermal conductivity of the compressed earth blocks to $0.75 \mathrm{~W} \mathrm{~m}^{-1} \mathrm{~K}^{-1}$ which remains insufficient to satisfy the thermal regulation requirements that depends on the wall thickness and in different regions of the world. Other investigations were undertaken to highlight various thermal conductivity measurement approaches in building construction materials. Meukam et al. [7] studied the thermal properties of lateritic soil bricks. The results show a rapid increase in thermal conductivity for lower water contents and a maximum diffusivity for a water content of $14 \%$ for laterite and $8 \%$ for laterite with the addition of natural pozzolan or sawdust. On the other hand, fibres are an important element of cob mixes, influencing thermal and hygric properties of cob walls in buildings. Their use also reduces the mix's final dried thermal conductivity [8]. Maddison et al. [9] investigated the humidity buffer capacity of clay-sand plaster. They measured the moisture quantity absorption/desorption under various climates. They found that the clay-sand plaster absorbs humidity more than it desorbs it. According to Ashour et al. [10], plaster materials are useful for straw bale buildings for their protection of the straw bale walls against the harsh external conditions. Laborel-Préneron et al. [11] studied the use of three bioresources (barley straw, corn cob, and hemp shiv) in the building field and demonstrated the use of these plant aggregates in an earth matrix, or a hydraulic, pozzolanic, air lime, or gypsum binder. They investigated water absorption, thermal conductivity, sorption and desorption isotherms, and density of the building materials. They found that straw gives the highest thermal resistance compared to hemp shiv and corn cob. They showed that the highest water absorption is obtained by hemp shiv and straw. More studies have focused on the analysis of the cases studies of existing earth buildings. Fgaier et al. [12] conducted experimental and theoretical investigations on the dynamic thermal behaviour of three types of industrial unfired earth bricks produced by the extrusion process, using different soils from various French quarries. They showed that, to achieve high thermal performance, the optimum thickness was $0.4 \mathrm{~m}$ for the soil containing a predominant concentration of silica and alumina and $0.3 \mathrm{~m}$ for the two other earth bricks, using soils with a larger amount of iron oxides for one and a significant concentration of $\mathrm{Al}_{2} \mathrm{O}_{3}$ for the other. The optimum thickness affords higher heat capacity and a thermal lag between 10 and $12 \mathrm{~h}$. Hadji et al. [13] investigated thermal conductivity of two types of earth materials obtained by mixing two kinds of soil with different amounts of straw. They showed that all the samples' thermal conductivity, tested with and without straw, are within the range 0.1 to $2 \mathrm{~W} \mathrm{~m}^{-1} \mathrm{~K}^{-1}$.

Although the literature is comprised of several studies focused upon the characterization of earth building materials properties, as presented above, the possibility of using local earth materials combined with available building techniques raises feasibility questions. Thus, Barnaure et al. [14] emphasized this aspect in their study, evaluating the use of local earth materials and traditional construction methods alongside the variability of properties based on the repeatability of tests and correlations. They used raw earth, manufactured from the Guérande region, with two formulations: without fibres or using hemp shiv and reed fibres. Results showed that the variability coefficient of the measured thermal conductivity is the highest for the measured samples with fibre contents from $8 \%$ up to 
$14 \%$. This was explained by the non-homogenous spreading and orientation of fibres in the mixes.

As most of the studies remain limited to laboratory characterization, rather than considering in situ prototyping to meet the construction regulations, Goodhew et al. [15] proposed a combination of two walling layers using earth materials $(\mathrm{Cob})$ to satisfy building regulations. The two layers are comprised of insulation with high fibre content and a load bearing layer with higher density. They showed that a cob mix of $398.73 \mathrm{~kg} / \mathrm{m}^{3}$ density provides a thermal conductivity of $0.12 \mathrm{~W} \mathrm{~m}^{-1} \mathrm{~K}^{-1}$. The proposed dual walling technique is able to satisfy the current UK and French thermal building standards within U-value of $0.30 \mathrm{~W} \mathrm{~m}^{-2} \mathrm{~K}^{-1}$. This standard must be achieved for all new buildings in France, England, and Wales

Given the above, there are many papers in the literature that deal with the thermal characterization of earthen materials already existing or that have been historically used, whereas other studies propose new bio-based mixes for construction within an overall thermal conductivity evaluation, using conventional measurement methods which do not include the effect of local fibres and soils nor their dispersion through the specimen. The variability of these properties across the same specimen depends mainly on the content of the soil and fibres alongside the selected manufacturing and construction techniques. This leads to questions on the effect of the un-homogenous distribution of fibres inside each earth formulation on local thermal properties and building energy efficiency. Moreover, the proposed cob dual walling concept requires an extended case study concerning its ability to provide promising results in terms of annual energy building conception, as the economic expenses represent a major factor in the promotion of eco-building alternative materials.

In this paper, a dynamic simulation of building energy efficiency is carried out by comparing conventional and cob buildings. The studied building represents a residential house of two floors with a weekly occupation scenario in two cities with nearly similar climatic conditions. The study comprises two major parts: the first part lies on studying the thermal performance of the building without heating and then, studying the energy performance of this house by evaluating the heat demand in the second part. Furthermore, thermal characterization of the new developed cob mixes has been carried through a new experimental procedure to measure the local thermal properties for various cob mixes. Distribution of the local thermal conductivity for each cob wall is related to the porosity and orientation of fibres in the mixes. Thermal conductivity, heat capacity, density, diffusivity, and effusivity of all the tested cob walls are investigated. This allows the selection of the highest thermal performance cob mix for the building prototypes construction based on the mixes within lower thermal conductivity, which means lower heat loss.

\section{Methodology and Experimental Investigations of Cob Material}

Dynamic modelling of the thermal performance of a residential house requires measurement of thermal properties of the selected cob materials used for house walls. The first investigation conducted in this work is the experimental study of cob mixes thermal properties characterization. The local thermal conductivity is studied to evaluate the average thermal conductivity regarding the effect of fibre distribution. The obtained results are compared in order to select the optimal thermal cob insulating and structural mixes for cob dual-wall construction. Various fibres within an absolute density range of $1.2 \mathrm{~g} \mathrm{~cm}^{-3}$ to $1.5 \mathrm{~g} \mathrm{~cm}^{-3}$ were provided: hemp straw, flax straw, reed, and wheat straw. Three different French soils were used in a dual cob layer composed of two different types of soil and fibres mixes (Figure 1). The first layer ensures the structural performance of the walls, and it is characterized by a high composition of soil and low composition of fibres (2.5 to $5 \%$ ). The second layer provides a high thermal resistance by using high composition of fibres $(25 \%)$ in the mixes. 


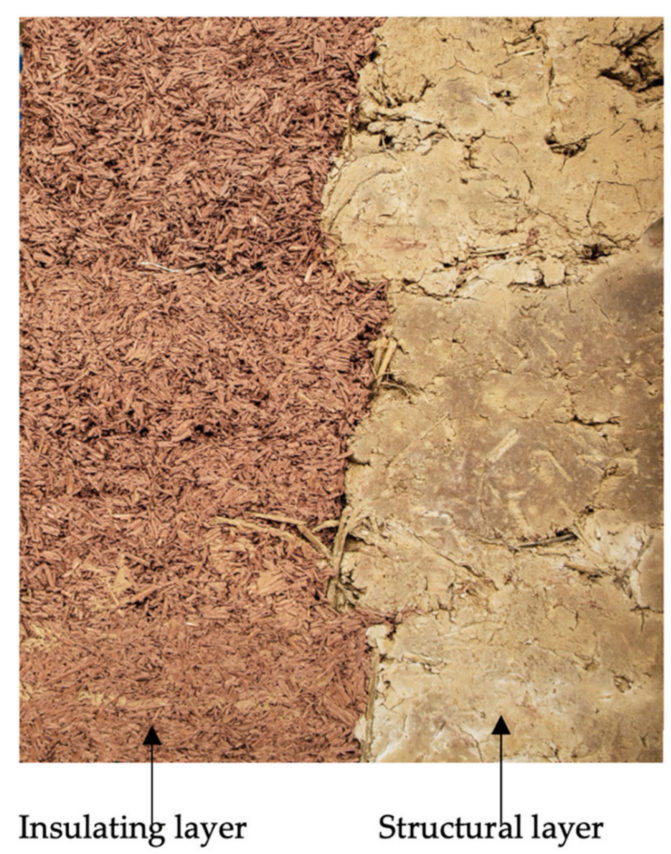

Figure 1. Photo of cob composite wall.

The use of a dual layer, respecting structural performance and thermal performance of building, provides a thinner wall $(300 \mathrm{~mm}$ for insulating cob layer and $400 \mathrm{~mm}$ for structural cob layer, as suggested by Goodhew et al. [15]) rather than a thick single cob layer using $1400 \mathrm{~mm}$ of thickness, as defined by Leguern et al. [16].

For the tested samples, soil is mixed with water and preserved for 3 days before adding fibres. Then, fibres are added, and the combination is left to dry at $50 \pm 5 \%$ one day before making samples. Afterwards, mixtures are divided into separate moulds for 2 days $(20 \mathrm{~cm} \times 20 \mathrm{~cm} \times 7 \mathrm{~cm})$, and they are then removed and kept in an oven at a temperature of $40^{\circ} \mathrm{C}$ for more than 7 days. The cob mixes contents studied in this work are presented in Table 1. Figure 2 shows photos of different structural cob mixes and insulating cob mixes specimens made with various soil, fibres, and water contents, as shown in Table 1.

Table 1. The composition of structural and insulating cob mixtures samples.

\begin{tabular}{|c|c|c|c|c|}
\hline Mixes type & Mix & Fibre type & Fibre Mass (\%) & Water Content (\%) \\
\hline \multirow{8}{*}{ Structural } & $\mathrm{S} 1$ & Hemp straw & 5 & 25 \\
\hline & $\mathrm{S} 2$ & Hemp straw & 5 & 28 \\
\hline & S3 & Hemp straw & 2.5 & 28 \\
\hline & S4 & Flax straw & 2.5 & 28 \\
\hline & S5 & Flax straw & 2.5 & 31 \\
\hline & S6 & Wheat straw & 2.5 & 31 \\
\hline & S7 & Reed & 2.5 & 31 \\
\hline & S8 & Wheat straw & 5 & 31 \\
\hline \multirow{2}{*}{ Insulation } & I1 & Reed & 25 & 131 \\
\hline & $\mathrm{I} 2$ & Hemp shiv & 25 & 131 \\
\hline
\end{tabular}




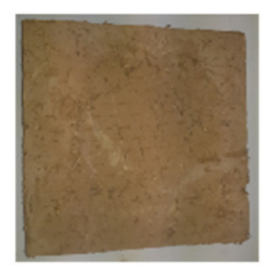

Mix S1

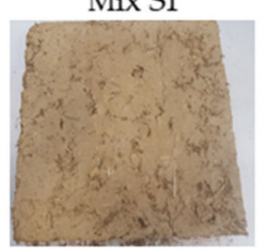

Mix S5

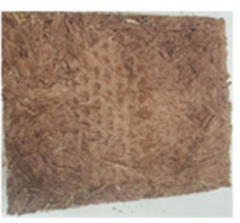

Mix I1

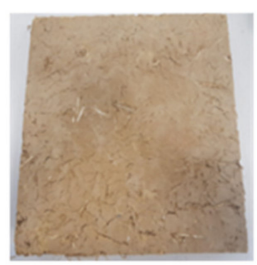

Mix S2

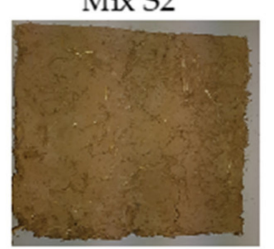

Mix S6

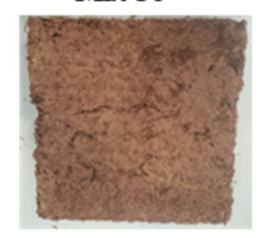

Mix I2

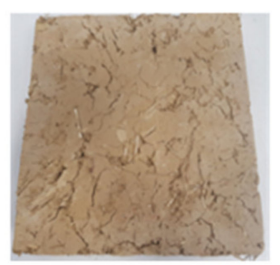

Mix S3

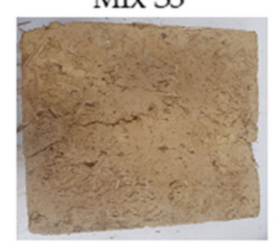

Mix S7

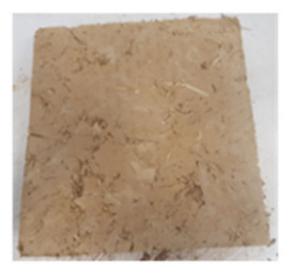

Mix S4

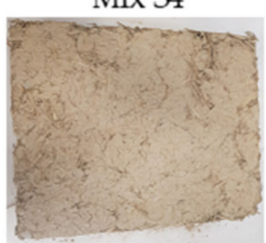

Mix S8

Figure 2. Photos of the studied structural and insulation cob samples.

\subsection{Test Section}

An experimental set up is built and calibrated in the laboratory to measure local thermal conductivity of the different cob samples, as shown in Figure 3. The experimental apparatus is mainly comprised of the test section (Figure 4) where the specimen is studied. Each specimen is placed between the upper cooling brass plate and lower heating brass plate for heat exchange through the material. The cooling brass plate is set under a copper micro grooved plate, using water as refrigerant within a cooling bath, thermostat, and $15 \mathrm{~L} \mathrm{~min}^{-1}$ pump capacity. The lower brass plate is heated with a rectangular heat cartridge, using a DC power supply with its power controlled and displayed using a wattmeter.

The test section is the main part of the experimental set up, built to measure local cob samples' thermal conductivity, as shown by Figure 4. It comprises a cooling brass plate in direct contact with the sample's top side and a brass heating plate in direct contact with the sample's bottom side. A highly conductive thermal paste is used to ensure good contact since the mixes have a rough surface. The heating side consists of a square heat cartridge in contact with the hot brass plate $(200 \mathrm{~mm} \times 200 \mathrm{~mm})$, instrumented with multiple K-type micro-thermocouples. To provide a good insulation around the test section, a $20 \mathrm{~mm}$ thick polyethylene expanded foam is used to cover the sample, heating and cooling plates, and $60 \mathrm{~mm}$ of expanded polystyrene is used for external side insulation. These insulated covers will reduce heat losses, through the lateral side face of the sample, into the surrounding environment.

The cooling square copper plate contains 50 parallel microchannels in which cold water flows at a controlled inlet temperature. Two K-type thermocouples are used to measure the inlet and outlet cooling water temperatures. Nine thermal zones of cold plate, hot plate, and cob sample are instrumented with K-type micro-thermocouples on both the top and bottom sides. Figure 5 shows the nine thermal zones on the cob samples. A multiple K-type micro-thermocouples (44 thermocouples) are used to measure local temperatures in the test section. Two Omega HFS-4 thin-film heat flux sensors are set at the cold and hot sides of the tested cob sample and have been connected to Keithley multimeters with $0.0012 \%$ DC voltage accuracy. The thermocouples have $\pm 0.1{ }^{\circ} \mathrm{C}$ error, and the heat flux measurements have a precision of $\pm 0.084 \mathrm{~W}$. 


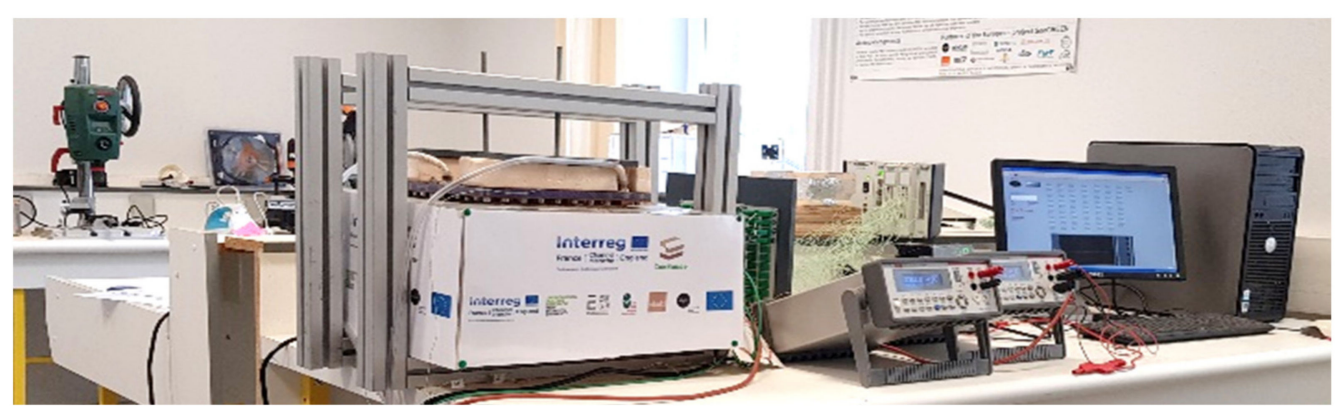

Figure 3. Experimental set up.

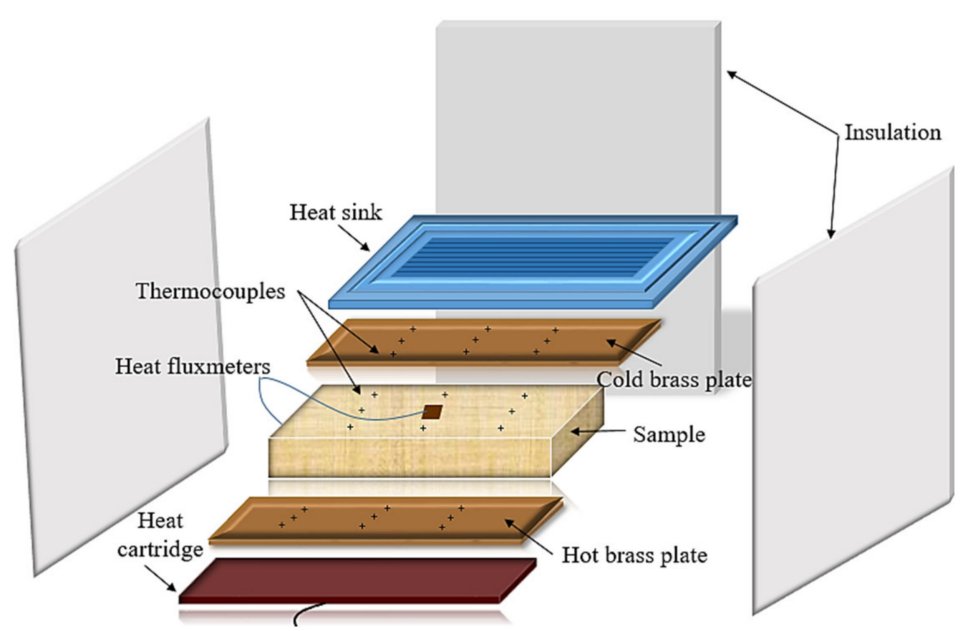

Figure 4. Test section.
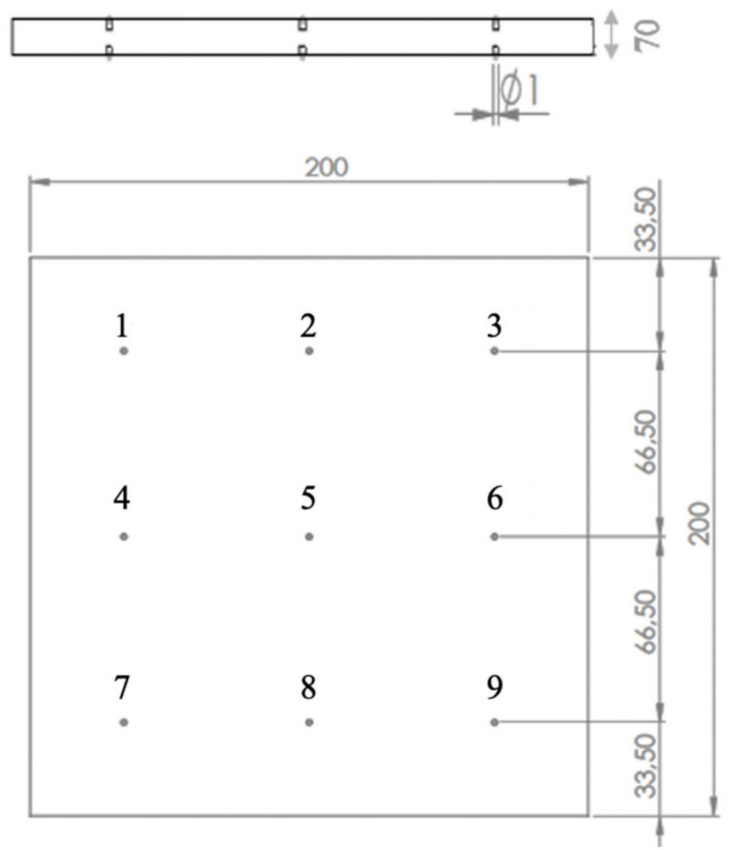

Figure 5. Thermal zones locations on the cob samples. 


\subsection{Experimental Procedure}

First, both brass plates are kept at a constant temperature to ensure constant initial heat flux, considering the thermal steady-state condition. Then, a temperature gradient is set at the bottom side, using the heat cartridge and kept constant, while the top side is cooled by water at the controlled inlet temperature. At the steady state, the local temperatures on the cob sample top $\left(\mathrm{T}_{\text {top, }, \mathrm{i}}\right)$ and bottom $\left(\mathrm{T}_{\text {bottom, }, \mathrm{i}}\right)$ sides and the average heat fluxes $\varphi_{\text {ave }}$ on both faces are recorded. The local thermal conductivity $\lambda_{\mathrm{i}}$, at each ' $\mathrm{i}$ ' location, is determined through the following equation:

$$
\lambda_{\mathrm{i}}=\frac{\varphi_{\mathrm{cp}}+\varphi_{\mathrm{hp}}}{2\left(\mathrm{~T}_{\mathrm{Bottom}, \mathrm{i}}-\mathrm{T}_{\mathrm{top}, \mathrm{i}}\right)}
$$

where $\varphi_{\mathrm{cp}}$ is the measured heat flux at the cob sample cold side, and $\varphi_{\mathrm{hp}}$ is the heat flux measured at the cob sample hot side.

All measuring devices are calibrated with respect to the measurement ranges of temperature, mass flow rate, and heat flux. Table 2 shows uncertainties on the measured parameters.

Table 2. Uncertainty of various parameters.

\begin{tabular}{lc}
\hline \multicolumn{1}{c}{ Parameters } & Uncertainty \\
\hline Heat flux $(\mathrm{W})$ & $\pm 10 \%$ \\
\hline Temperature $\left({ }^{\circ} \mathrm{C}\right)$ & \pm 0.1 \\
\hline Distance $(\mathrm{mm})$ & \pm 0.5 \\
\hline Thermal conductivity $\left(\mathrm{W} \mathrm{m}^{-1} \mathrm{~K}^{-1}\right)$ & $\pm 10 \%$ \\
\hline
\end{tabular}

\subsection{Materials and Test Method}

Experiments are conducted using the structural and insulation cob samples showed in Figure 6. For all the tested structural and insulation materials, local thermal conductivity is determined for each sample in the nine zones. The variation of local thermal conductivity distribution is due to the heterogeneous distribution of fibres and soils in the cob mixes. The type and the content of fibres and soils still have a major influence on the thermal characterization of the mixes besides the impact of the shape and thickness of fibres.

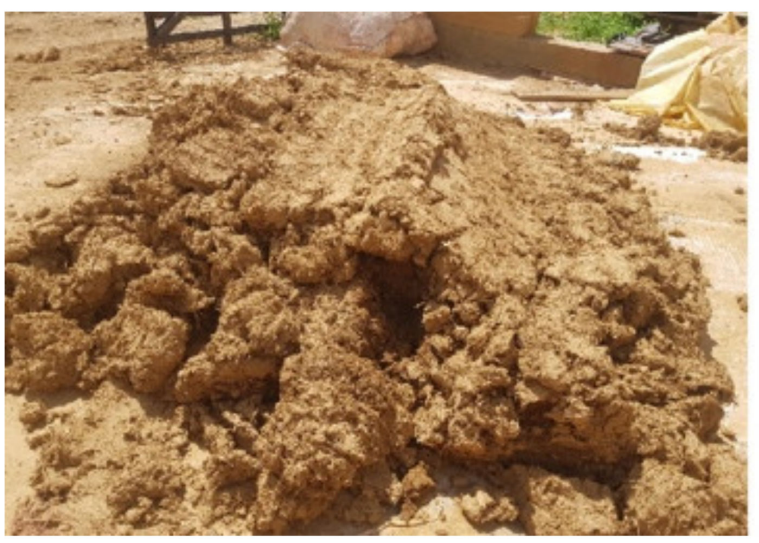

(a)

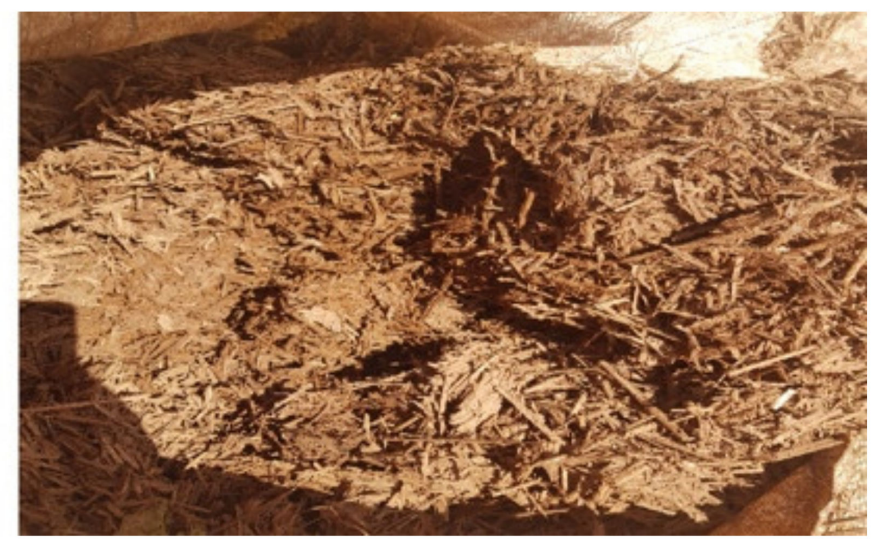

(b)

Figure 6. Photos of the studied cob mixes: (a) structural cob material, (b) insulation cob material.

\section{Cob Building Thermal Performance Modelling}

The thermal performance of two buildings is evaluated using a building heat loss dynamic simulation program without providing any heating sources. The dynamic simu- 
lation is investigated using TRNSYS software considering a Typical Meteorological Year (TMY). The standard used for TRNSYS simulations corresponds to the French thermal regulation RT2012 [17]. Building simulation incorporates the calculation elements required by the French energy efficiency standard that requires residential buildings to have a primary energy consumption lower than $50 \mathrm{kWh} \mathrm{m}^{-2}$ per year. Thermal performance of a residential house with cob mixes walls is investigated, and the results are compared to those obtained for a conventional house. A comparison is conducted in terms of the interior building temperature, comfort, and heating loads.

Two single residential houses with two floors are investigated. Figure 7 shows the single house plan for the ground and the first floor. Cob and conventional buildings ${ }^{\prime}$ thermal performances are evaluated in two cities: Caen city (France) and Plymouth city (United Kingdom) and for average coldest and hottest days data over 10 years. Table 3 shows the lowest, highest, mean temperatures, and maximum mean solar radiation for two typical days: one in winter and one in summer. Table 4 presents materials used for the composition of walls, ceilings, and floors of the two studied houses. Thickness of each material and its conductivity are also detailed in Table 4. Figure 8 a shows a $728 \mathrm{~mm}$ thick cob building composite wall, which is made from $13 \mathrm{~mm}$ of lime plaster, $300 \mathrm{~mm}$ of insulating cob mix, $400 \mathrm{~mm}$ of structural cob mix layer, and $15 \mathrm{~mm}$ of raw earth. As presented in Figure 8b, the wall of a conventional house includes four basis construction layers, including an external coating layer thickness of $15 \mathrm{~mm}, 200 \mathrm{~mm}$ layer of cement hollow brick for building structural performance, $150 \mathrm{~mm}$ thickness of glass wool for building thermal performance, and $13 \mathrm{~mm}$ thickness of standard plaster.
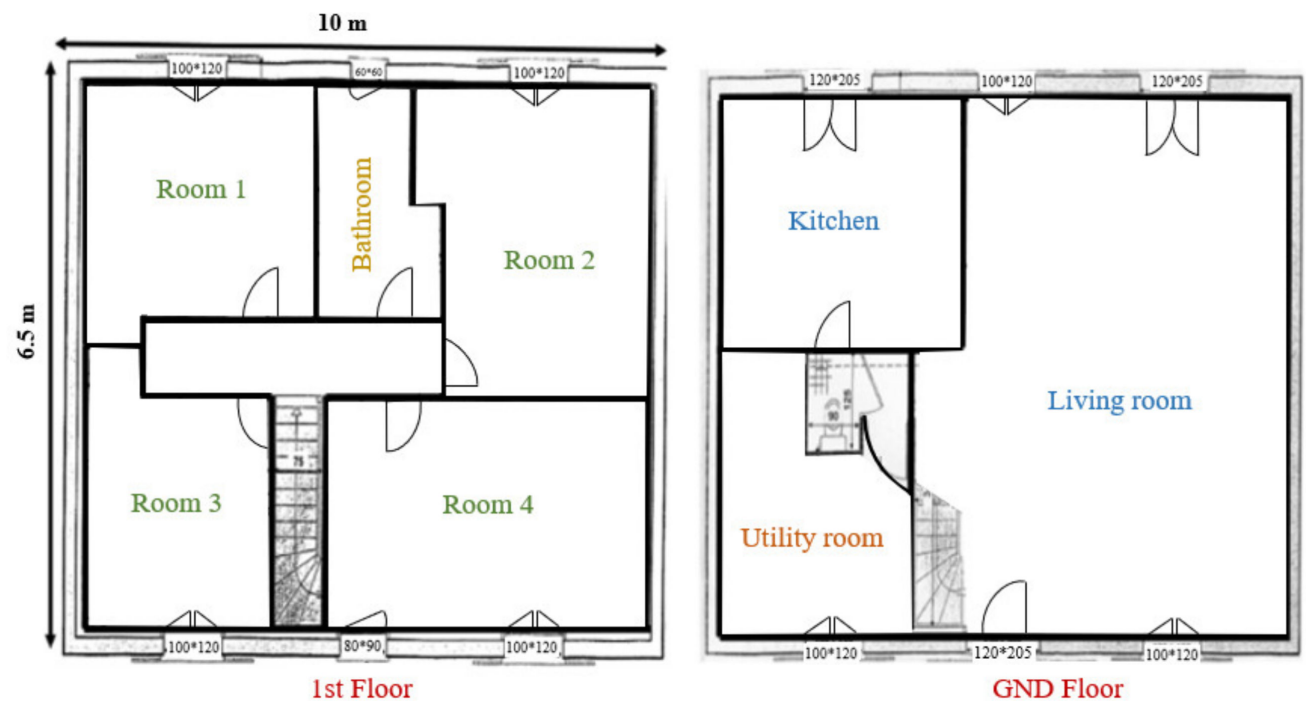

Figure 7. House plan for the ground floor and the first floor.

Table 3. Climatic characteristics of the coldest and hottest days.

\begin{tabular}{ccccc}
\hline Days & Lowest $\mathbf{T}\left({ }^{\circ} \mathbf{C}\right)$ & Highest T $\left({ }^{\circ} \mathbf{C}\right)$ & Mean T $\left({ }^{\circ} \mathbf{C}\right)$ & $\begin{array}{c}\text { Maximum Mean Solar } \\
\text { Radiation } \mathbf{~} \mathbf{~ m}^{-2}\end{array}$ \\
\hline 11 Jan & -9.56 & -3 & -7.15 & 250 \\
\hline 21 July & 13.7 & 33 & 24.5 & 975 \\
\hline
\end{tabular}


Table 4. The walls, ceiling, and floor composition for cob and conventional buildings.

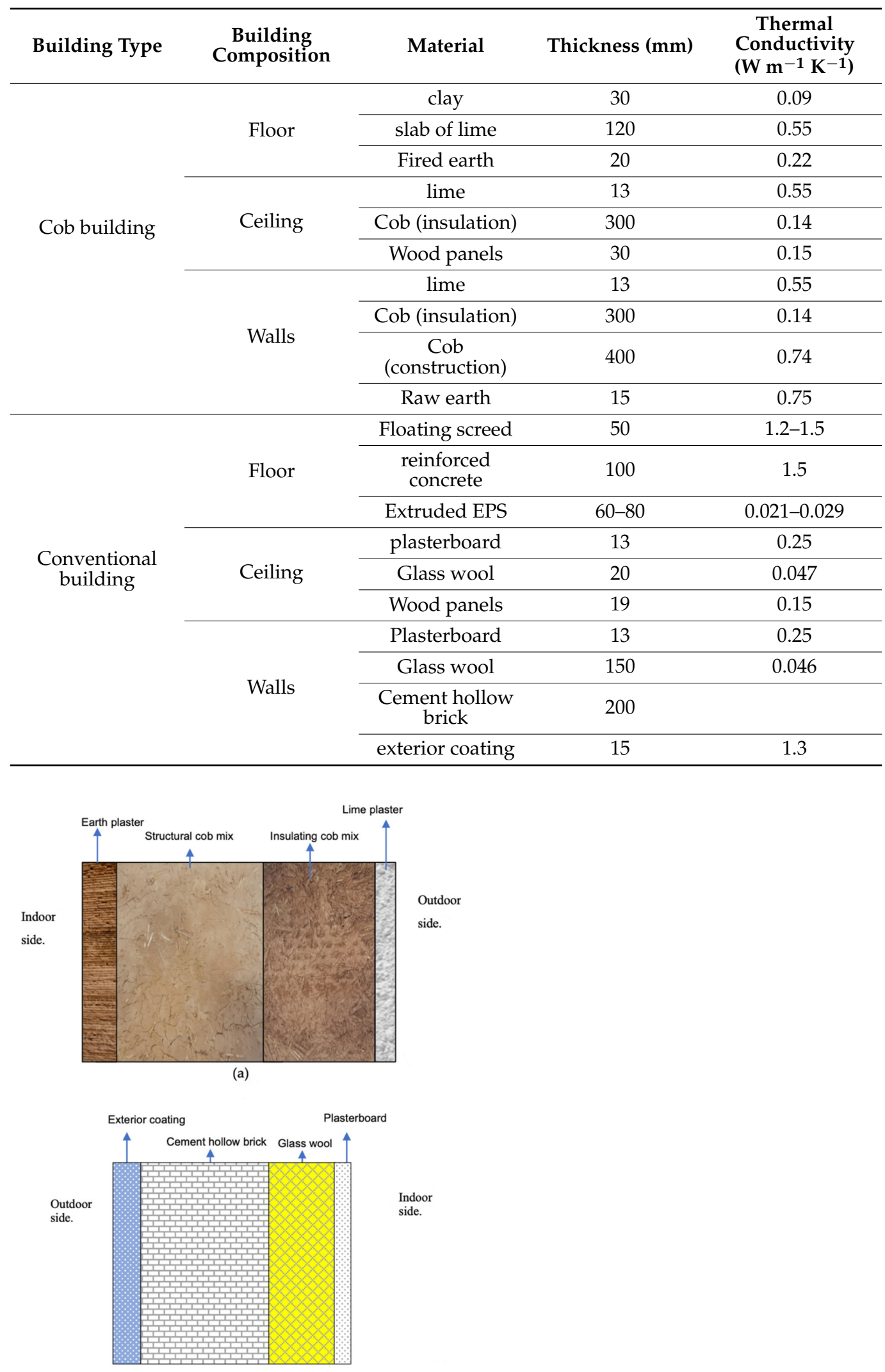

(b)

Figure 8. Wall composition for: (a) cob building and (b) conventional building. 


\section{Results and Analysis}

\subsection{Cob Mixes Thermal Conductivity}

Examples of local thermal conductivity measurement are reported for one insulating cob mix and one structural cob mix in Figure 9. The structural and insulating samples with lowest average thermal conductivity are selected for this investigation because of their highest thermal resistance. The structural cob sample is constituted by the French sub-soil, wheat straw fibres content ( $5 \%$ of total mass), and water content (31\%). The insulating cob sample has $25 \%$ of Reed and $131 \%$ of water content. As shown by Figure 9, for both cob samples, the local thermal conductivity is not uniform. That is mainly due to the fibres distribution on the cob mixes. For both cob samples, the relative standard deviation is computed as the standard deviation of the 9 thermal zone measurements divided by the average value of these measurements. It is about $18 \%$ for the structural cob sample and $7 \%$ for the insulating cob sample.

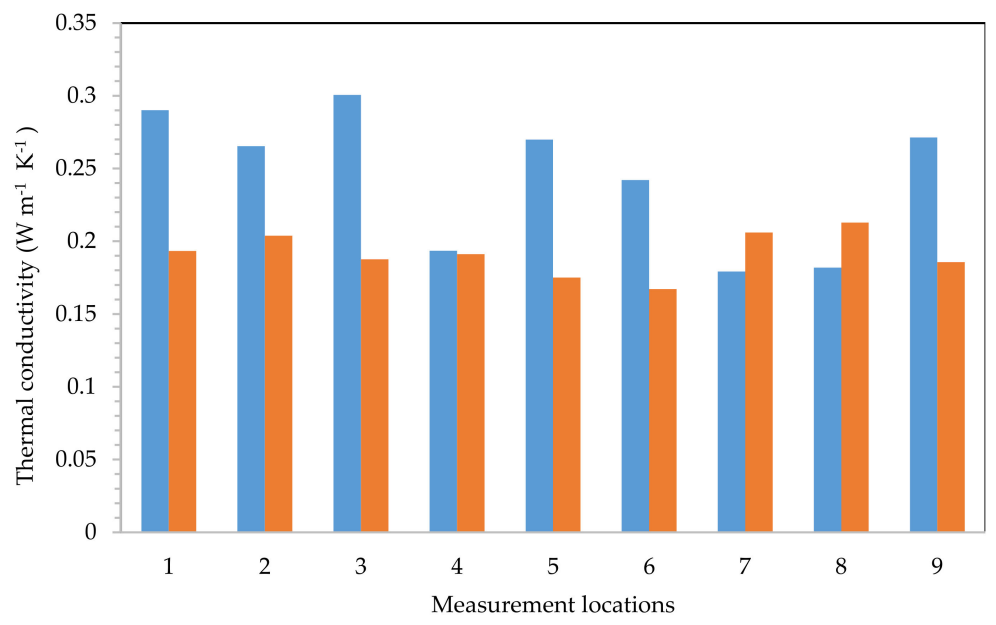

Figure 9. Local thermal characterization of the cob structural and cob insulating samples.

Average thermal conductivity for each tested cob sample is then determined as the mean value of the local thermal conductivities on the 9 thermal zones. A comparison of the average thermal conductivity of different structural and insulation cob materials is presented in Figure 10. The lowest average thermal conductivity (about $0.244 \mathrm{~W} \mathrm{~m}^{-1} \mathrm{~K}^{-1}$ ) is obtained for the structural material with $5 \%$ of wheat straw fibres content, which represents the optimal structural mix that prevents the greatest loss of heat from the building. The highest thermal conductivity, about $0.75 \mathrm{~W} \mathrm{~m}^{-1} \mathrm{~K}^{-1}$, is obtained for the structural cob mix within the $2.5 \%$ small fibres content. The most insulating cob mix has an average thermal conductivity of $0.19 \mathrm{~W} \mathrm{~m}^{-1} \mathrm{~K}^{-1}$ using $25 \%$ of reed fibres.

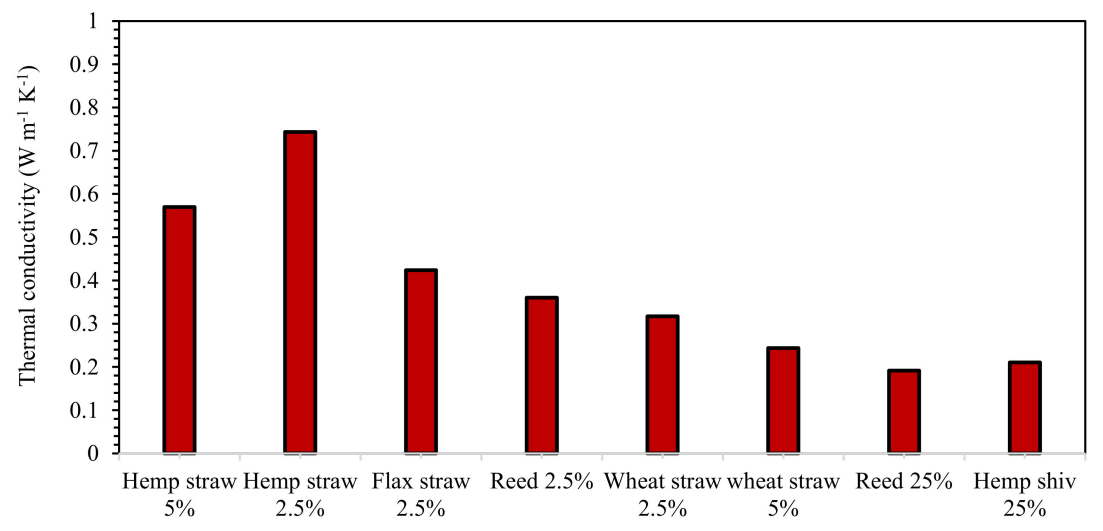

Figure 10. Average thermal conductivity of the cob mixes. 


\subsection{Cob Thermal Diffusivity, Effusivity, Heat Capacity and Density}

In the building sector, thermal inertia stabilizes the indoor ambient temperature and contributes to thermal comfort and the limitation of energy consumption. Two types of inertia are considered: the inertia by transmission and the inertia by absorption.

The variation of the French outside temperature of the building is high in summer and influences the inside temperature of the building because of heat transfer across the walls. Building inertia by transmission can slow down the heat transfer from the outside of the building walls to the inside building walls and, therefore, reduce the building's inside temperature. It can limit the need for air conditioning in summer by using low diffusive materials and night-time ventilation. Absorptive inertia can also stabilize the inside temperature of the building in summer, through the process of storing and releasing heat, using highly effusive materials. The effusive capacity of the walls contributes to the improvement of the thermal comfort, of the buildings in summer, in a passive way. When the inside temperature of the building exceeds the comfort temperature, the walls absorb heat until a stable temperature is reached. This heat is then released when the inside temperature of the building drops below its comfort value. Absorption inertia can also help to reduce heating consumption in winter.

The inertia by transmission, characterized by the thermal diffusivity, defines the capacity of the material to slow down the heat transfer. The thermal diffusivity is defined as

$$
D=\frac{\lambda}{\rho C}
$$

where $\lambda$ is the thermal conductivity, $\rho$ is the density, and $C$ is the heat capacity.

The inertia by absorption is characterized by the effusivity, which determines the capacity of the material to store/unstore heat and regulate the indoor temperature. It is characterized by the thermal effusivity calculated using the following equation

$$
E=\sqrt{\lambda \rho C}
$$

The inertia by transmission and by absorption is maximum if the material diffusivity is minimal, and the material effusivity is maximum.

The density and heat capacity of the cob mixes have been measured, enabling the evaluation of the samples' heat capacity, as it represents a key parameter for building heat transfer dynamic simulation. The cob samples basis weight is measured using an electronic balance with $\pm 0.1 \mathrm{~g}$ accuracy. The density is computed as the fraction of the cob sample weight and its volume. The density of cob mixes are presented in Figure 11, varying from $1107 \mathrm{~kg} \mathrm{~m}^{-3}$ to $1583 \mathrm{~kg} \mathrm{~m}^{-3}$ for structural samples, and less than $700 \mathrm{~kg} \mathrm{~m}^{-3}$ for insulation samples. Therefore, it can be seen that the structural samples are characterized by their high density compared to insulation samples, mostly due to fibre contents in each sample. These results embody the inverse relationship between density and porosity created by the junction between fibres and soils. The crossing of these fibres creates dispersing pores and voids in the mixes which, in turn, increases a sample's porosity whenever the amount of fibres is large. Thus, the insulation samples have more fibre content $(25 \%)$, which explains low density values due to high levels of mix porosity. Heat capacity has been determined using thermal conductivity, diffusivity, and density, and the obtained results are presented in Figure 11.

Results show that, for thermal conductivity lower than $0.4 \mathrm{~W} \mathrm{~m}^{-1} \mathrm{~K}^{-1}$, if the cob density is low, its insulation capacity is better, and its heat capacity is higher. In this range of thermal conductivity, the cob thermal conductivity could be estimated using the following correlation:

$$
\lambda=0.0002 \rho+0.05
$$




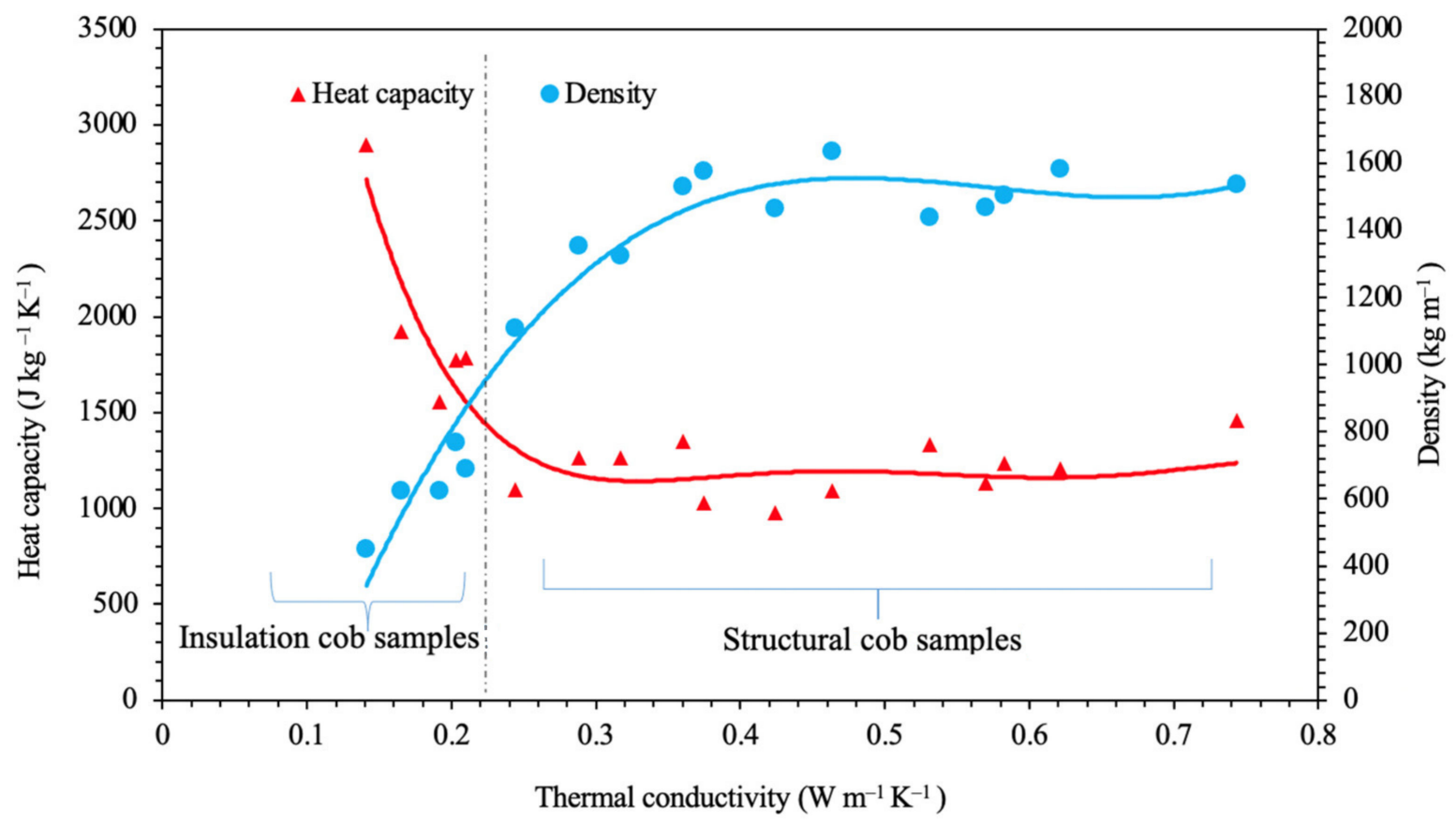

Figure 11. Density and heat capacity of the cob samples versus thermal conductivity.

For cob mixes of a thermal conductivity higher than $0.4 \mathrm{~W} \mathrm{~m}^{-1} \mathrm{~K}^{-1}$, the density and heat capacity are approximately constant; the average density is $1519 \mathrm{~kg} \mathrm{~m}^{-3}$, and the average heat capacity is $1205 \mathrm{~J} \mathrm{~kg}^{-1} \mathrm{~K}^{-1}$. The relative standard deviation computed in this range of thermal conductivity is about $3 \%$ for density and $8 \%$ for heat capacity.

- The results obtained here are compared with those already published concerning thermal properties of earth-based materials. Al Rim et al. [18] obtained a linear relation for clay-cement-wood mixtures:

$$
\lambda=0.22810^{-3} \rho-0.006
$$

This correlation agrees with our results, as shown in Figure 12, for thermal conductivity between 0.15 and $0.3 \mathrm{~W} \mathrm{~m}^{-1} \mathrm{~K}^{-1}$ and densities between 400 and $1300 \mathrm{~kg} \mathrm{~m}^{-3}$. Similar and closed results are overserved by Labat et al. [19] on straw clay samples. Authors observed that thermal conductivity increases from 0.07 to $0.17 \mathrm{~W} \mathrm{~m}^{-1} \mathrm{k}^{-1}$ when density increases from 200 to $780 \mathrm{~kg} \mathrm{~m}^{-3}$. Laborel et al. [20] found that thermal conductivity of earth-barley straw, hemp shiv, and corn cab materials are close to $0.3-0.5 \mathrm{~W} \mathrm{~m}^{-1} \mathrm{~K}^{-1}$ when density is $1600-1800 \mathrm{~kg} \mathrm{~m}^{-3}$. This value is limited to the plateau values presented in Figure 11 of the present study. According to Laborel et al., thermal conductivity increases with density because bulk density decreases. However, it can be noted, in Figure 11, that the density of the material hardly changes any more for the samples whose conductivity is between 0.4 and $0.75 \mathrm{~W} \mathrm{~m}^{-1} \mathrm{~K}^{-1}$. Laborel et al. also observed this type of trend. When densities of materials are lower than $1200 \mathrm{~kg} \mathrm{~m}^{-3}$, the thermal conductivities published by several authors are homogeneous. When the density is higher, the thermal conductivities vary greatly, as observed in the results of the present study. 


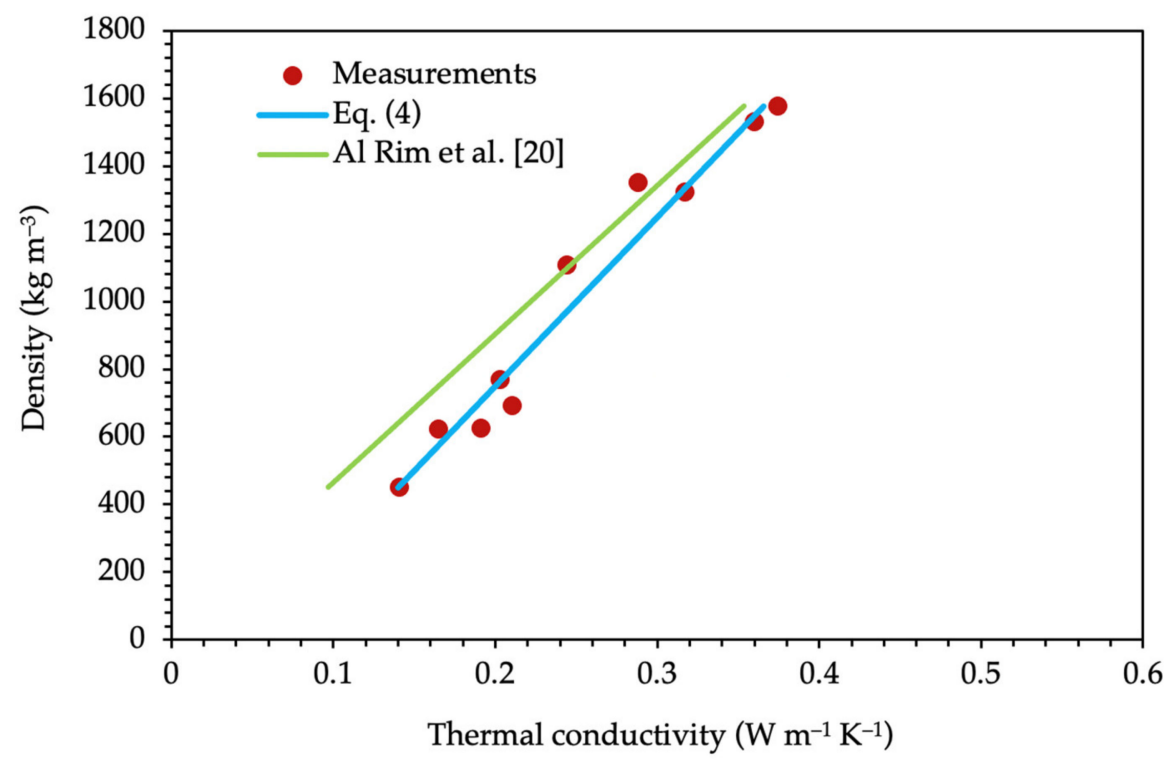

Figure 12. Density and heat capacity of the cob samples versus thermal conductivity.

When the density is low, typically below $1300 \mathrm{~kg} \mathrm{~m}^{-3}$, the heat transfer is mainly driven by the resistance in the air bulks, very present in materials heavily loaded with fibres. As many authors suggest, thermal conductivity can be established as a linear function of density [10-20]. When the density is higher than approximately $1300 \mathrm{~kg} \mathrm{~m}^{-3}$, the thermal conductivity no longer varies linearly with the density. The structure of material contains few bulk elements, and the transfer is mainly driven by conduction in the aggregate materials which strongly depends on the nature of the aggregate used.

Meukam et al. [21] have measured the heat capacity of cement-stabilized laterite bricks using an adiabatic calorimeter and obtained a value of $1000 \mathrm{~J} \mathrm{~kg}^{-1} \mathrm{~K}^{-1}$. Additionally, Cagnon et al. [22] measured the heat capacity of five extruded earth bricks that ranged from 900 to $960 \mathrm{~J} \mathrm{~kg}^{-1} \mathrm{~K}^{-1}$, which approaches the obtained results for structural mixes when fibre content is low.

Both thermal diffusivity and effusivity, which represent the rate of heat transfer from a hot side to a cold side, are calculated to provide enough thermal characterization for cob thermal performance. Results for all the samples are also presented in Figure 13. Thermal diffusivity reaches a high value for the sample S2 of $0.342 \mathrm{~mm}^{2} \mathrm{~s}^{-1}$ and low value of $0.168 \mathrm{~mm}^{2} \mathrm{~s}^{-1}$ for structural mixes, while the highest thermal diffusivity is evaluated around $0.19 \mathrm{~mm}^{2} \mathrm{~s}^{-1}$ for $\mathrm{T} 5$, and the lowest insulation mix diffusivity measured is $0.1 \mathrm{~mm}^{2} \mathrm{~s}^{-1}$. On the other hand, effusivity reaches its lowest value at $428 \mathrm{~J} \mathrm{~m}^{-2} \mathrm{~s}^{-1 / 2}$ for construction mixes, as they are characterized by higher thermal conductivity, which makes them less able to store heat. Meanwhile, the highest value is noticed for insulating mixes within a maximum value of $1290 \mathrm{~J} \mathrm{~m}^{-2} \mathrm{~s}^{-1 / 2}$. This can be explained by the fact that insulating mixes have an important ability to store energy, providing better thermal indoor comfort.

As shown in Figure 13, materials with low effusivity have low diffusivity, and those with maximum effusivity also have maximum diffusivity. To improve thermal comfort, it is therefore necessary to use two different materials, the first one of which has low diffusivity and is located in the external side of the building wall (insulating material with diffusivity of $0.14 \mathrm{~mm}^{2} \mathrm{~s}^{-1}$ ). The second must be of maximum effusivity and will be placed in the internal side of the building wall as a structural material (effusivity of $1290 \mathrm{~J} \mathrm{~m}^{-2} \mathrm{~K} \mathrm{~s}^{-1 / 2}$ ). Thus, a dual wall, using joined cob structural and cob insulating mixes, will be considered in the model to study cob building energy performance. 


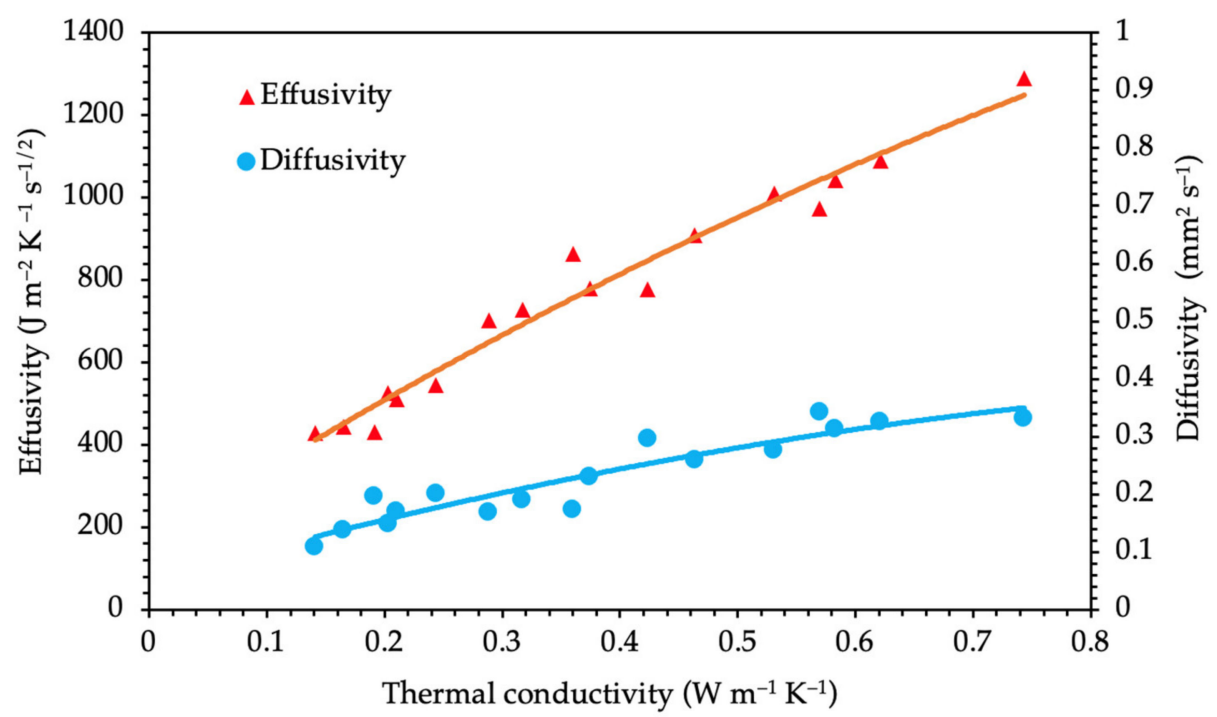

Figure 13. Thermal effusivity and diffusivity versus thermal conductivity.

\subsection{Cob building Thermal Performance}

\subsubsection{Cob Building Thermal Performance without Indoor Heating Source}

The thermal study aims to evaluate the building behaviour in both cases when exposed to lower outdoor temperatures without providing any indoor heating resources. Figure 14 shows the obtained results of the mean indoor temperature of all the house parts for $\mathrm{cob}$ and conventional cases for the coldest day in Caen city. The mean conventional indoor temperature tends to decrease drastically from $16^{\circ} \mathrm{C}$ to $6{ }^{\circ} \mathrm{C}$, which means a $10{ }^{\circ} \mathrm{C}$ drop in $24 \mathrm{~h}$, while a temperature drop in the cob building is about $0.5^{\circ} \mathrm{C}$ for the same duration. This is explained by the dual walling cob capacity to store heat which is far greater than conventional building besides the $\mathrm{U}$-value effect which combines low thermal conductivity with an important cob thickness $(700 \mathrm{~mm})$. Moreover, Figure 15 shows the outdoor and indoor temperatures during the hottest day. Indoor temperature, in the case of a conventional building, can be seen to be increasing when the outdoor temperature rises, reaching $27^{\circ} \mathrm{C}$ when the outdoor temperature reaches $33^{\circ} \mathrm{C}$. Due to the conventional materials inertia, the indoor temperature continues rising even if the outdoor temperature has dropped, which represents another thermal effect of using these materials. However, cob construction materials seem to conserve a comfortable indoor temperature thanks to its heat storage and transmitting properties, as discussed previously. A mean temperature is calculated for different house parts and compared, with the cob building showing a remarkable capacity to maintain a comfortable indoor temperature, even during the more extreme climatic conditions. These results agree with temperature representation through the year for both cases, as presented in Figure 16. Indeed, combining the inertial thermal properties of cob with its heat capacity and the important thickness used for its construction enables temperature auto regulation that provides comfortable indoor conditions. 


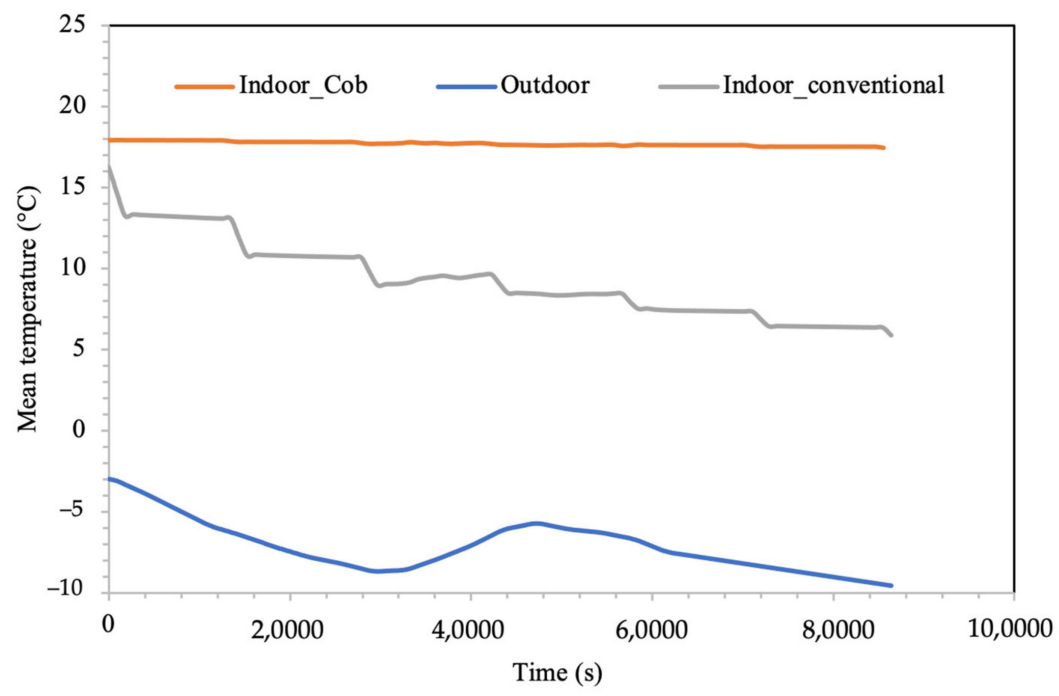

Figure 14. Indoor and outdoor temperature during the coldest day without heating.

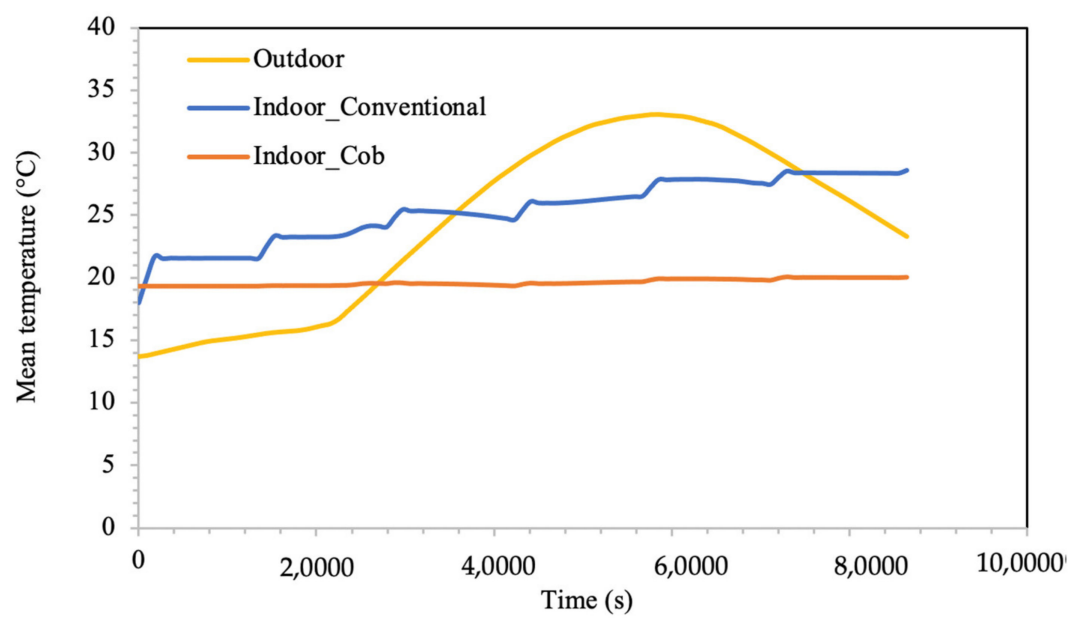

Figure 15. Indoor and outdoor temperature during the hottest day.

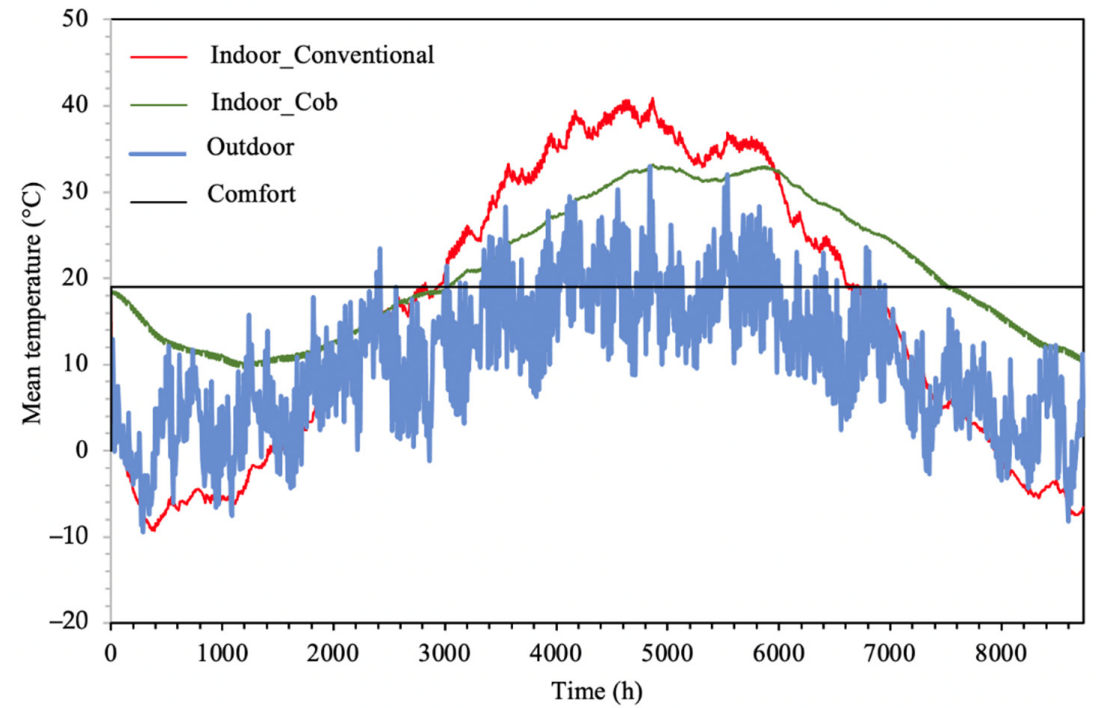

Figure 16. Indoor and outdoor temperature throughout a year. 


\subsubsection{The Cob and Conventional Buildings Heating Need}

With the thermal building study showing that the cob building has a great potential for temperature auto-regulation, this paragraph details an energy performance investigation based on heat demand.

As this French-English project incorporates a solid partnership collaboration, a case study, and comparison between two cities, Caen from the French side and Plymouth from the English side, is conducted. The particularity of this project is working on common characteristics shared between both regions. Climatic conditions are one of them, as it is presented in Figure 17. The data in this figure are generated through Meteonorm software. In fact, Caen and Plymouth mean temperature over the past 10 years is nearly similar with higher registered temperature noticed at Caen city.

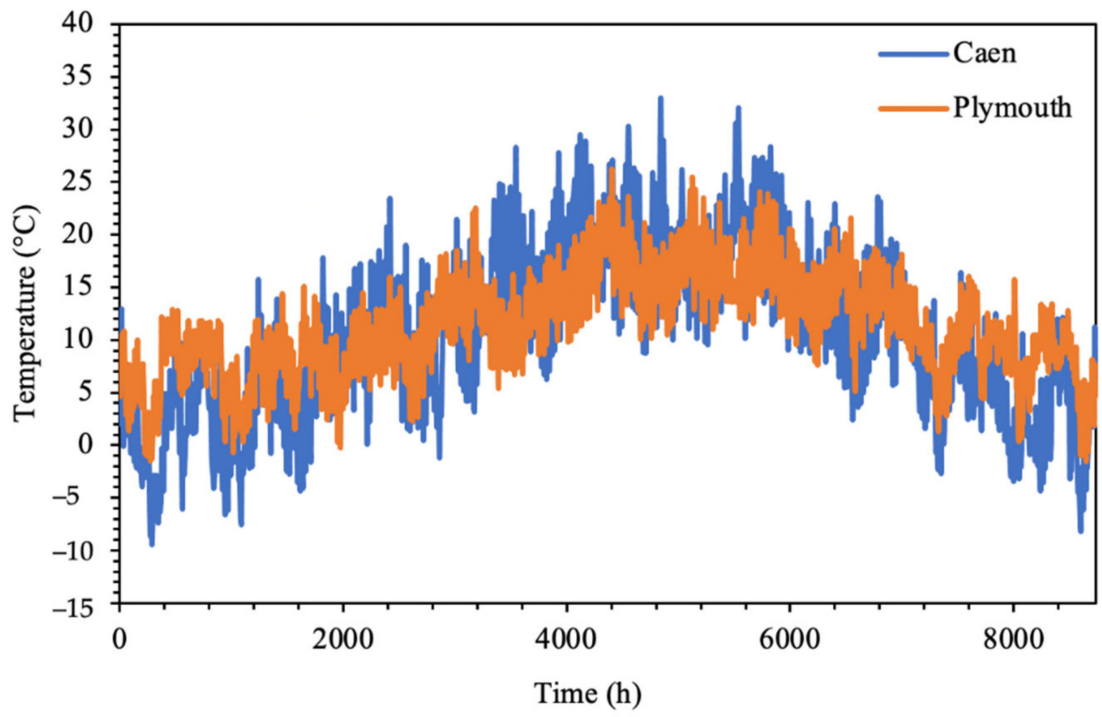

Figure 17. Mean outdoor temperature over ten years in Caen and Plymouth.

First, the building is considered to be occupied over the studied days, except during working hours, between 8 AM and 6 PM, as shown in Figure 18 for week occupation, where 1 stands for occupation and 0 for non-occupation, without considering non-occupation due to vacations, to simplify the study. During the non-occupation time a set temperature is required as recommended from city authorities to avoid water freezing inside the pipes which is fixed as $12{ }^{\circ} \mathrm{C}$ in this study. Figure 19 shows the obtained results of the mean indoor temperature of all the house parts for cob and conventional cases for the coldest day. During the unoccupied hours, the heating system is turned off, which explains the temperature decrease for the conventional case. However, using cob, the temperature of the indoor is maintained even during the unoccupied hours thanks to its heat storage capacity, which shows that cob provides an effective thermal comfort by reducing heat losses and preserving indoor temperature. The heating demand is also calculated based on temperature difference, which corresponds to the same explanation given previously. Indeed, no heating is required for the cob building when there is no occupation, as temperature is maintained below the set temperature, while heating demand is noticed for a conventional building to maintain temperature below $12{ }^{\circ} \mathrm{C}$ (Figure 20). 


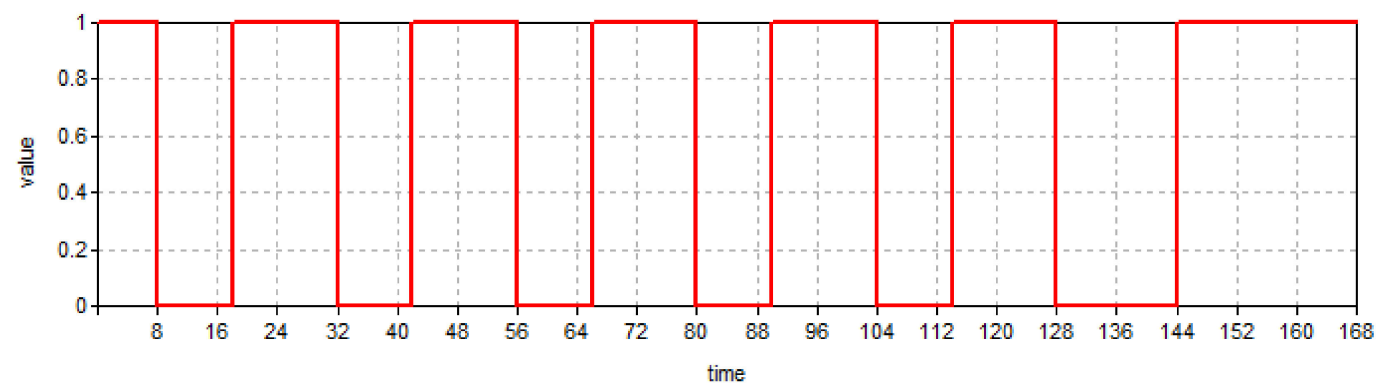

Figure 18. Week occupation scenario.

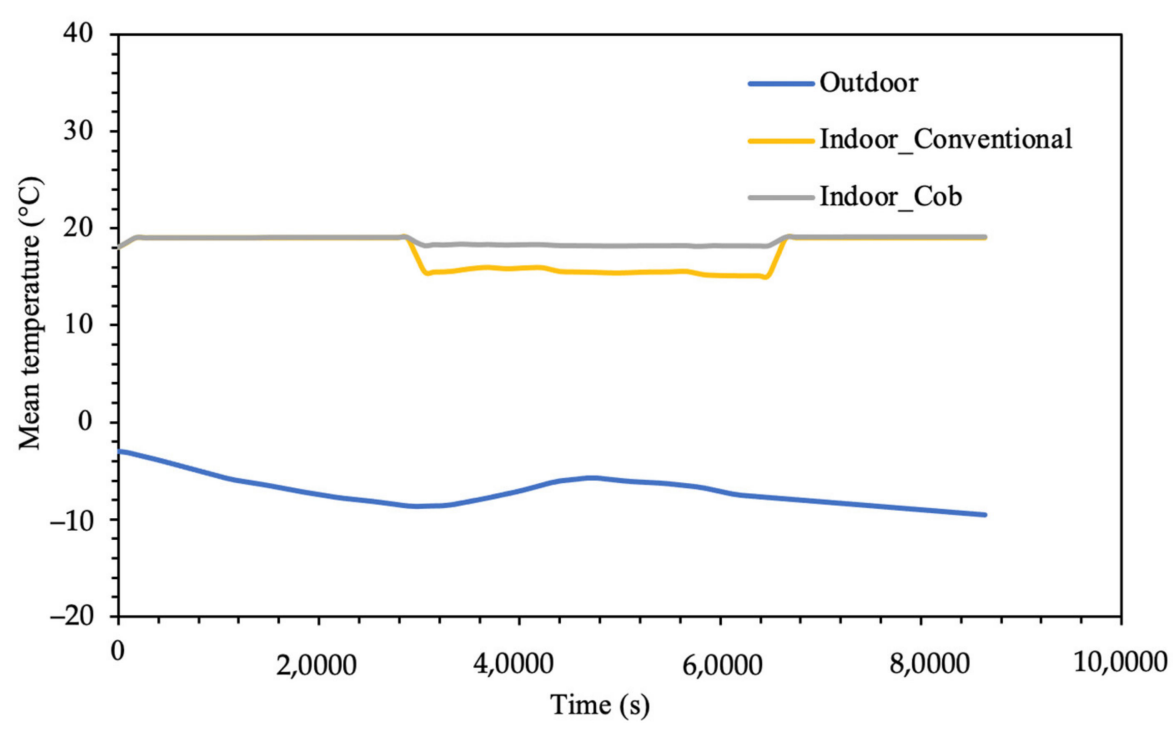

Figure 19. Mean indoor temperature for the two cases in the coldest day.

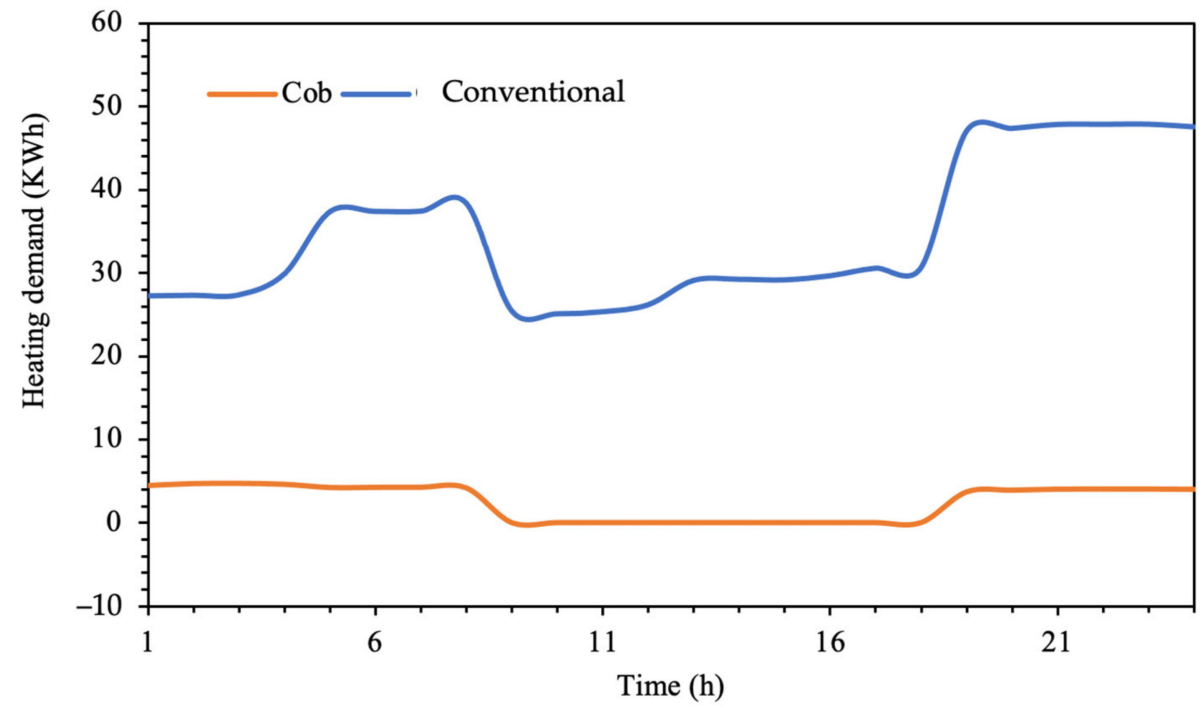

Figure 20. Heating demand for cob and conventional building.

The heating demand is calculated for both the cob and conventional building per area in each month and is represented in Figure 21. The obtained results agree with thermal performance, studied in the previous section, as the cob building provides efficient thermal regulation thanks to the thermal properties of the dual walling composition detailed in the 
experimental measurements. This enables less energy consumption throughout the year, unlike the conventional building that reaches $114.88 \mathrm{kWh} \mathrm{m}^{-2}$ for January as the coldest month of the year.

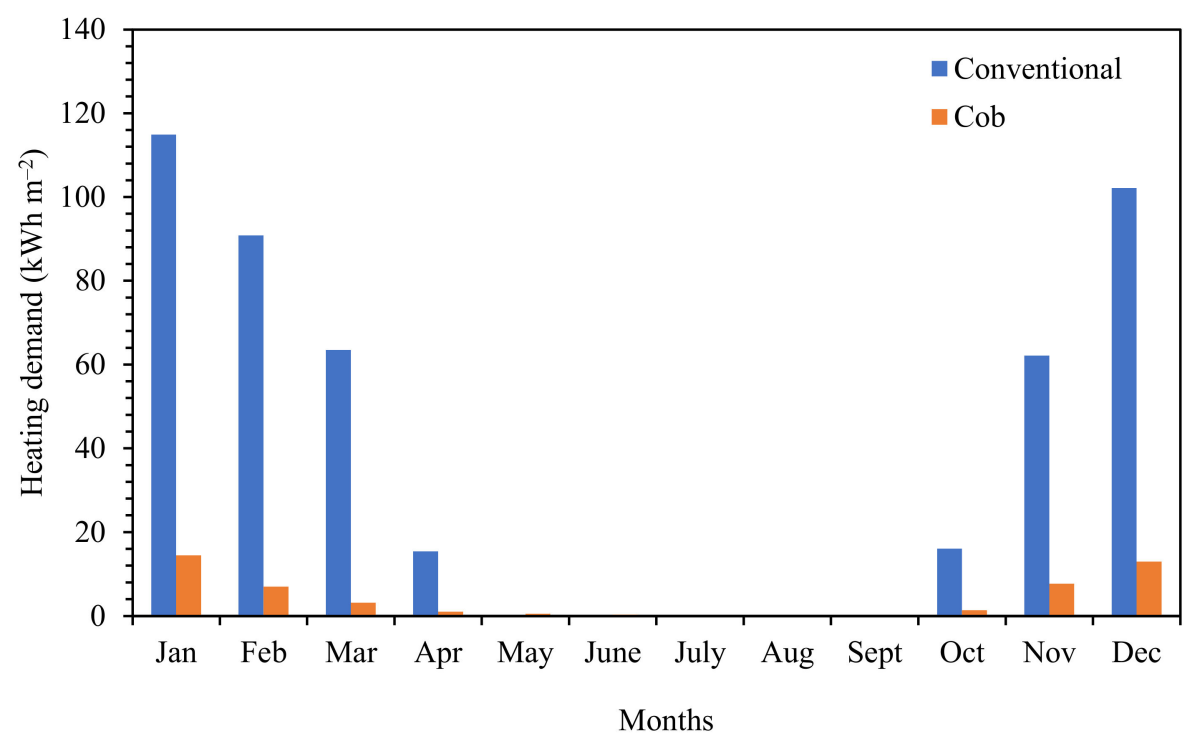

Figure 21. Heating demand for cob and conventional building over a year.

Based on the provided climatic database, heating demand is calculated for both cities and both cases (Figure 22). These results also agree with what was demonstrated previously, as the cob materials enable efficient thermal comfort with less heating energy consumption, besides its eco-friendly property, with less embodied $\mathrm{CO}_{2}$ compared to a conventional building. Therefore, it can be deduced that a cob dual-wall building could be considered an innovative material, respecting the use of $50 \mathrm{kWh} \mathrm{m}^{-2}$ per year and less $\mathrm{CO}_{2}$ emissions, as required by the French Regulations norm in 2020.

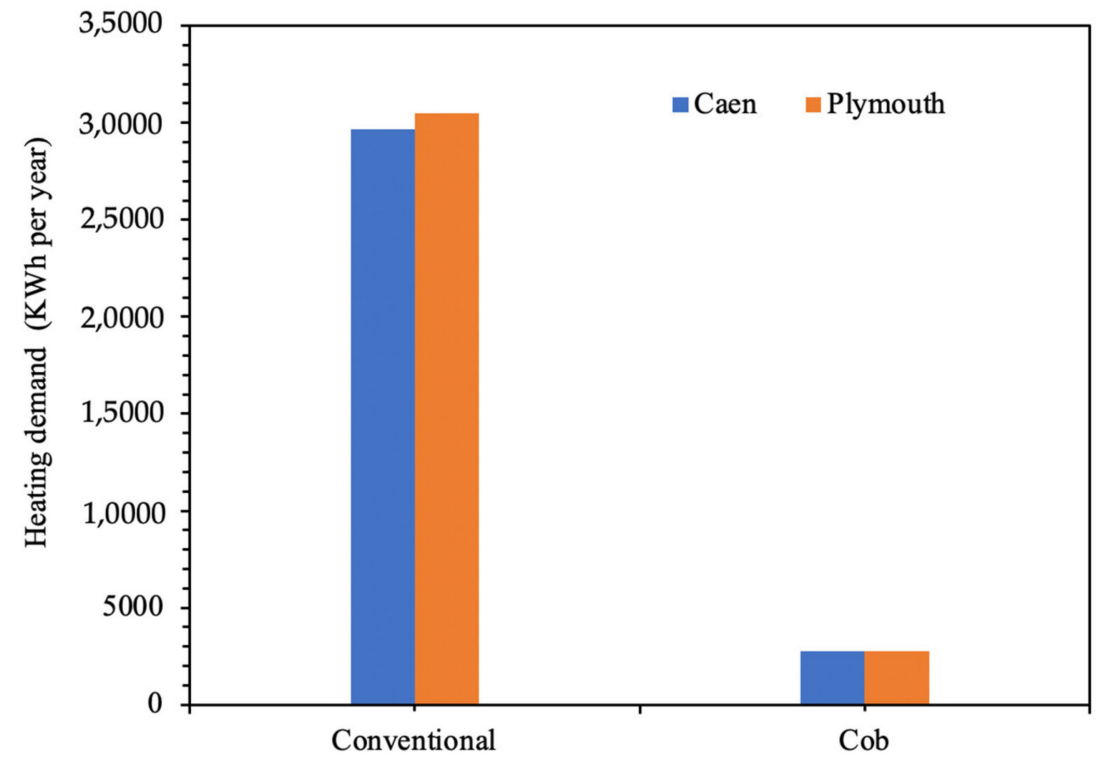

Figure 22. Mean outdoor temperature over ten years in Caen and Plymouth.

\section{Conclusions}

In this paper, thermal properties of raw earth-based building materials are investigated. The present cob mixtures are made of French soils and fibres: reed, wheat straw, hemp 
shiv, hemp straw, and flax straw. Cob mixtures for high structural performances and cob mixtures for high insulation performances are studied using different densities, various mixes of French soils and different water contents. Experimental set-up is developed to measure the local and average thermal conductivity and thermal diffusivity of the samples. Density of samples are also established by separately measuring the mass and volume whereas heat capacities are calculated using the previous values and Equation (2).

Experimental results show that densities of structural samples vary from $1107 \mathrm{~kg} \mathrm{~m}^{-3}$ to $1583 \mathrm{~kg} \mathrm{~m}^{-3}$, whereas densities of insulation samples are less than $700 \mathrm{~kg} \mathrm{~m}^{-3}$.

For all samples tested, the measured local thermal conductivity is not uniform and can vary greatly from one area to another. Local conductivity can vary up to $25 \%$ around the average thermal conductivity of the sample. Standard deviation of local thermal conductivity is $18 \%$ for the structural cob sample and $7 \%$ for the insulating cob sample.

The lowest average thermal conductivity of the structural sample is $0.244 \mathrm{~W} \mathrm{~m}^{-1} \mathrm{~K}^{-1}$. It is obtained for the sample containing heart, $5 \%$ wheat straw, and $31 \%$ of water. Thermal conductivity of structural samples can increase up to $0.75 \mathrm{~W} \mathrm{~m}^{-1} \mathrm{~K}^{-1}$. The lowest average thermal conductivity of the insulation sample is $0.19 \mathrm{~W} \mathrm{~m}^{-1} \mathrm{~K}^{-1}$. It is obtained for the material containing earth, $25 \%$ reed, and $131.1 \%$ water. The results showed that, for the most part, the insulating samples showed an increase in thermal conductivity with density. Thermal conductivity varies from 0.19 to $0.4 \mathrm{~W} \mathrm{~m}^{-1} \mathrm{~K}^{-1}$ when density varies between 400 and $1300 \mathrm{~kg} \mathrm{~m}^{-3}$. In this range of thermal conductivity, the cob thermal conductivity could be estimated using:

$$
\lambda=0.0002 \rho+0.05
$$

When the density is higher than approximately $1300 \mathrm{~kg} \mathrm{~m}^{-3}$, the thermal conductivity no longer varies linearly with the density. When thermal conductivity varies from $0.4 \mathrm{~W}$ to $0.76 \mathrm{~W} \mathrm{~m}^{-1} \mathrm{~K}^{-1}$, measured densities are between 1400 and $1600 \mathrm{~kg} \mathrm{~m}^{-3}$, and no significant variation is noticed. Similar results are observed for calculated heat capacity, which varies slightly from 500 to $800 \mathrm{~J} \mathrm{~kg}^{-1} \mathrm{~K}^{-1}$ when thermal conductivity varies from $0.4 \mathrm{~W}$ to $0.76 \mathrm{~W} \mathrm{~m}^{-1} \mathrm{~K}^{-1}$. This trend was observed for structural samples.

Thermal performance of a cob building is investigated using a TRNSYS dynamic simulation program. The program simulates the climatic conditions of an entire year based on meteorological data from the French city of Caen and the English city of Plymouth. The interior home temperature was established, without a heating device, for a cob house and compared with a house made with conventional materials. The results show that the cob house exhibits a much more stable interior temperature than the house made of conventional materials. This was due to the high thermal inertia of structural cob. Likewise, the thermal amplitudes observed between winter and summer for a cob house are much lower than for a house made of conventional materials. Simulations including a heating system show that the cob house heating demand is significantly lower than for the house made of conventional materials. These results show that the high insulating performance $\mathrm{cob}$ and high structural performance cob are very promising binomial materials for the construction of buildings. It has a great capacity for thermal regulation and allows a domestic scale building to obtain a comfortable interior temperature while requiring very little heating.

Author Contributions: Conceptualization, K.Z., H.L. and M.M.; methodology, K.Z. and H.L.; software, K.Z., A.G.; validation, K.Z., A.G.; formal analysis, K.Z., A.G., H.L.; investigation, K.Z., H.L., M.M.; writing—original draft preparation, K.Z.; writing—review and editing, K.Z., H.L., S.G.; supervision, H.L.; project administration and funding acquisition, M.B., S.G., F.S. All authors have read and agreed to the published version of the manuscript.

Funding: This work is conducted under CobBauge project selected by the European cross-border cooperation program INTEREG V France (Manche)-England. It was funded by the European Regional Development Fund (ERDF).

Institutional Review Board Statement: Not applicable. 
Informed Consent Statement: Written informed consent has been obtained from the patient(s) to publish this paper.

Acknowledgments: In This work is conducted under Cobbauge project selected by the European cross-border cooperation program INTEREG V France (Manche)-England. The authors would like to thank ERDF for the funding of this work.

Conflicts of Interest: The authors declare no conflict of interest.

\section{References}

1. Huo, H.; Jinga, C.; Li, K.; Huo, H. Synergic relationships between thermophysical properties of wall materials in energy-saving building design. Int. J. Heat Mass Tran. 2015, 90, 246-253. [CrossRef]

2. International Energy Agency. Tracking Buildings Report. Tracking Report-June 2020; International Energy Agency: Paris, France, 2020.

3. Painuly, J.P.; Park, H.; Lee, M.K.; Noh, J. Promoting energy efficiency financing and ESCOs in developing countries: Mechanisms and barriers. J. Clean. Prod. 2003, 11,659-665. [CrossRef]

4. Mora, E.P. Life cycle, sustainability and the transcendent quality of building materials. Build. Environ. 2007, 42, 1329-1334. [CrossRef]

5. Goodhew, S.; Griffiths, R. Sustainable earth walls to meet the building regulations. Energy Build. 2005, 37, 451-459. [CrossRef]

6. Mansour, M.B.; Jelidi, A.; Cherif, A.S.; Jabrallah, S.B. Optimizing thermal and mechanical performance of compressed earth blocks (CEB). Constr. Build. Mater. 2016, 104, 44-51. [CrossRef]

7. Meukam, P.; Jannot, Y.; Noumowe, A.; Kofane, T.C. Thermo physical characteristics of economical building materials. Constr. Build. Mater. 2004, 18, 437-443. [CrossRef]

8. Ashour, T.; Wieland, H.; Georg, H.; Bockisch, F.J.; Wu, W. The influence of natural reinforcement fibres on insulation values of earth plaster for straw bale buildings. Mater. Des. 2010, 31, 4676-4685. [CrossRef]

9. Ashour, T.; Georg, H.; Wu, W. An experimental investigation on equilibrium moisture content of earth plaster with natural reinforcement fibres for straw bale buildings. Appl. Therm. Eng. 2011, 31, 293-303. [CrossRef]

10. Maddison, M.; Mauring, T.; Kirsimäe, K.; Mander, Ü. The humidity buffer capacity of clay-sand plaster filled with phytomass from treatment wetlands. Build. Environ. 2009, 44, 1864-1868. [CrossRef]

11. Laborel-Préneron, A.; Magniont, C.; Aubert, J.E. Characterization of barley straw, hemp shiv and corn cob as resources for bioaggregate based building materials. Waste Biomass Valorization 2018, 9, 1095-1112. [CrossRef]

12. El Fgaier, F.; Lafhaj, Z.; Antczak, E.; Chapiseau, C. Dynamic thermal performance of three types of unfired earth bricks. Appl. Therm. Eng. 2016, 93, 377-383. [CrossRef]

13. Sanjaya, C.S.; Wee, T.H.; Tamilselvan, T. Regression analysis estimation of thermal conductivity using guarded-hot-plate apparatus. Appl. Therm. 2011, 31, 1566-1575. [CrossRef]

14. Barnaure, M.; Bonnet, S.; Poullain, P. Earth buildings with local materials: Assessing the variability of properties measured using non-destructive methods. Constr. Build. Mater. 2021, 281, 122613. [CrossRef]

15. Goodhew, S.; Boutouil, M.; Streiff, F.; Le Guern, M.; Carfrae, J.; Fox, M. Improving the thermal performance of earthen walls to satisfy current building regulations. Energy Build. 2021, 240, 110873. [CrossRef]

16. Leguern, M.; Sebaibi, N.; Boutouil, M. Technical Report Cobbauge Project. Soil and Fibre Characterisation, Mixes Choice and Mixes Characteristics; ESITC Caen: Épron, France, 2018.

17. Arrêté du 28 Décembre 2012 Relatif aux Caractéristiques Thermiques et aux Exigences de Performance Énergétique des Bâtiments Nouveaux et des Parties Nouvelles de Bâtiments Autres que ceux Concernés par L'Article 2 du Décret du 26 Octobre 2010 Relatif aux Caractéristiques Thermiques et à la Performance Énergétique des Constructions. JORF 2012, 46, 97.

18. Al Rim, K.; Ledhem, A.; Douzane, O.; Dheilly, R.M.; Queneudec, M. Influence of the proportion of wood on the thermal and mechanical performances of clay-cement-wood composites. Cem. Concr. Compos. 1999, 21, 269-276. [CrossRef]

19. Labat, M.; Magniont, C.; Oudhof, N.; Aubert, J.E. From the experimental characterization of the hygrothermal properties of straw-clay mixtures to the numerical assessment of their buffering potential. Build. Environ. 2016, 97, 69-81. [CrossRef]

20. Laborel-Préneron, A.; Magniont, C.; Aubert, J.E. Hygrothermal properties of unfired earth bricks: Effect of barley straw, hemp shiv and corn cob addition. Energy Build. 2018, 178, 265-278. [CrossRef]

21. Meukam, P.; Noumowe, A.; Jannot, Y.; Duval, R. Thermophysical and mechanical characterization of stabilized clay bricks for building thermal insulation. Mater. Struct. 2003, 36, 453-460.

22. Cagnon, H.; Aubert, J.E.; Coutand, M.; Magniont, C. Hygrothermal properties of earth bricks. Energy Build. 2014, 80, 208-217. [CrossRef] 